\title{
The Dynamic Input-Output Model of Distribution Network Upgrading Project Under the Background of Electric Internet of Things
}

\author{
Zhibin Yan ${ }^{1}$, Li Xiang ${ }^{1}$, Ye Lu² ${ }^{2}$, Wei Zheng ${ }^{1}$, Gaoqiang $\mathrm{Qu}^{1}$, Jian Kang ${ }^{1}$ and Lisha You ${ }^{2}$ \\ ${ }^{1}$ State Grid Ningxia Electric Power Company, Yinchuan, China \\ ${ }^{2}$ School of Economics and Management, North China Electric Power University, Changping District, Beijing, China
}

\begin{abstract}
China is promoting the construction of electric internet of things, and a large part of the fixed asset investment in the power grid is the investment in the upgrading of the distribution network. The economic benefits of investment are related to the sustainable development of power grid companies. At present, the Chinese government is reforming transmission and distribution tariff, and the economic benefits of power grid infrastructure investment are facing greater uncertainty. This paper studies the life cycle cost of the distribution network upgrading project from construction to decommissioning and the electricity revenue for the entire operation period. The dynamic input-output model of the distribution network upgrading project is established under the background of electric internet of things. An empirical analysis is conducted in combination with the case study. Through load forecasting and cost calculation, the input and output indicators of the project are obtained, which verifies the validity and accuracy of the model.
\end{abstract}

\section{Introduction}

The power Internet of things fully applies modern information and communication technology to realize the interconnection of everything in all aspects of the power system. The power Internet of things provides sufficient and effective information and technical support for planning, construction, production and operation, business management, comprehensive services and other aspects.

In the perception layer of electric internet of things, effective infrared image recognition can achieve realtime monitoring of equipment status. In order to improve the quality of image recognition, an image enhancement algorithm based on membership function is proposed in this paper (Liu et al.,2019). In the application of power grid automation, the author gives the idea of data collection, analysis and visualization of power grid automation holographic intelligent operation and control system, and designs the detailed scheme of automatic holographic intelligent operation and control system, which can provide reference for the construction of power grid automation holographic intelligent operation and control system (Han et al.,2020). The author analyzed the access requirements and functional requirements of power IoT construction. Combined with the top-level architecture design of "cloud-tube-edgeend" of State Grid Corporation, a architecture design of the new power IoT back-end system was proposed (Chen et al.,2020).

Transmission and distribution tariff reform is the core content of China's electric power system reform. The size of transmission and distribution tariff is mainly determined by grid assets and transmission and distribution costs. Therefore, grid investment and transmission and distribution tariff affect each other (He et al.,2015). Transmission and distribution tariff determine the revenue of grid companies, affect the financial situation of grid companies, and affect the ability of grid companies to invest in the future (Wang et al.,2019). There is a large demand for power grid investment. Under the constraints of limited investment funds, it is necessary to comprehensively evaluate the investment income of the power grid (Luo et al.,2011). Most grid investment funds are used for grid infrastructure construction. The cost-benefit analysis of distribution network upgrading projects determines whether the project meets the principle of economic benefits (Alaqeel and Suryanarayanan,2019).

China's existing grid investment decisions mainly consider technical factors, rarely consider economic returns, and lack a comprehensive consideration of revenue and costs during the life cycle of grid assets.This paper analyzes the life-cycle income and costs of distribution network upgrading projects, establishes dynamic input-output model under the background of electric internet of things, and verifies the applicability of the model through empirical analysis.

\section{Dynamic Input-Output Model of Distribution Network Upgrading Project}

\footnotetext{
"Corresponding author: luye1933@163.com
} 
The characteristics of distribution network upgrading projects are large investment scale and long capital recovery period. The main goals are to ensure the security of the power grid and meet the load demand. At the same time, the economic benefits of project investment should be taken into account to achieve highquality development of power grid companies. This chapter mainly analyzes the input and output of distribution network upgrading projects, analyzes the economic benefits of the projects, and provides support for grid investment decisions. The input-output analysis process is shown in Fig.1.

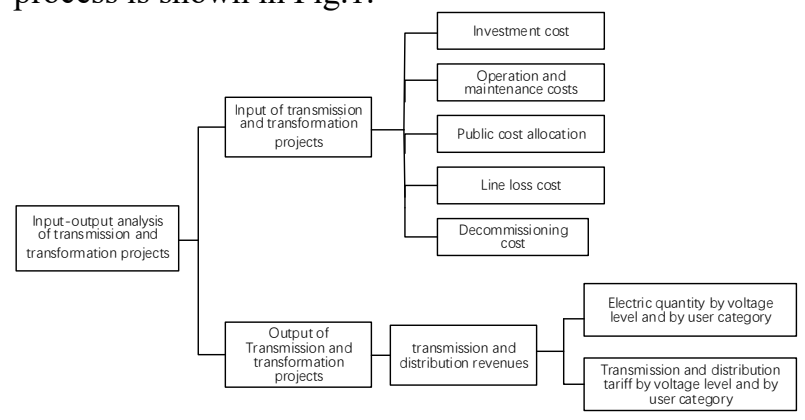

Fig. 1. Input-output analysis of distribution network upgrading projects.

\subsection{Construction of Life Cycle Input Model for Distribution Network Upgrading Projects}

The life cycle cost of distribution network upgrading projects refers to the expenses incurred during the project investment construction, operation maintenance and decommissioning. The calculation formula for the life cycle cost of power grid infrastructure is as follows:

$$
C_{L C C}=\sum_{t=1}^{T}\left[\left(C_{1}^{t}+C_{2}^{t}+C_{3}^{t}+C_{4}^{t}+C_{5}^{T}\right) \times \frac{1}{(1+i)^{t}}\right]
$$

where $C_{L C C}$ represents the life cycle cost of the grid infrastructure, $\mathrm{T}$ represents the life cycle, $\mathrm{t}$ represents the operating year, $C_{1}^{t}$ represents the initial investment cost, $C_{2}^{t}$ represents the operation and maintenance cost, $C_{3}^{t}$ represents the utility cost allocation, $C_{4}^{t}$ represents the line loss cost, $C_{5}^{T}$ represents the decommissioning cost, and $i$ represents the benchmark rate of return, $\frac{1}{(1+i)^{t}}$ represents the discount coefficient.

\subsection{Construction of Life Cycle Output Model for Distribution Network Upgrading Projects}

China adopts the form of transmission and distribution tariff divided by voltage level. This chapter first calculates the revenue of the relevant regional power grid, and then multiplies it by the distribution ratio of the distribution network upgrading project to obtain the life cycle revenue of the distribution network upgrading project.

(1) Calculation of power grid transmission and distribution income in relevant areas of distribution network upgrading projects
The power transmission and distribution income includes the income of power transmission and distribution of large industrial users and the income of power transmission and distribution of the commercial. The formula is as follows:

$$
I_{1}^{t}=I_{1, d}^{t}+I_{1, g}^{t}
$$

where $I_{1}^{t}$ represents the transmission and distribution income in the relevant regional power grid. $I_{1, d}^{t}$ represents the transmission and distribution income of large industrial users. $I_{1, g}^{t}$ represents the transmission and distribution income of the commercial.

The calculation formula for the transmission and distribution income of large industrial users is as follow.

$$
I_{1, d}^{t}=\sum_{m=1}^{12}\left(M_{m}^{t} \times p_{a}^{t}\right)+\sum_{i=1}^{4} \sum_{h=1}^{8760}\left(p_{1, d, i}^{t} \times f_{d, i, h}^{t} \times \lambda_{1, d, i}^{t}\right)
$$

where $\mathrm{m}$ represents the month, $M_{m}^{t}$ represents the transformer capacity or the maximum demand of the large industrial users, $p_{a}^{t}$ represents the corresponding basic electricity price, and i represents the voltage level, including four variables: 1, 2, 3, and 4, respectively representing four voltage levels of $220 \mathrm{kV}, 110 \mathrm{kV}, 35 \mathrm{kV}$, and $10 \mathrm{kV}, \mathrm{h}$ represents 8760 periods of the year, corresponding to peak, peak, flat, trough, and double storage periods. $p_{1, d, i}^{t}$ represents the power transmission and distribution tariff of the $\mathrm{i}$-th voltage level of the $\mathrm{t}$-th year for large industrial users. $f_{d, i, h}^{t}$ represents the load of the $\mathrm{i}$-th voltage of $\mathrm{h}$ period in the $\mathrm{t}$-th year for large industrial users.

The formula for calculating the income from transmission and distribution of the commercial is as follows:

$$
I_{1, g}^{t}=\sum_{i=1}^{5} \sum_{h=1}^{8760}\left(p_{1, g, i}^{t} \times f_{g, i, h}^{t} \times \lambda_{1, g, i}^{t}\right)
$$

where, i represents the voltage level, including five variables of $1,2,3,4$, and 5, respectively representing five voltage levels of $220 \mathrm{kV}, 110 \mathrm{kV}, 35 \mathrm{kV}, 10 \mathrm{kV}, 1 \mathrm{kV}$ and below. $p_{1, g, i}^{t}$ represents the power transmission and distribution tariff for the commercial. $\lambda_{1, g, i}^{t}$ represents the load value of the the commercial.

(2) Research on revenue sharing mechanism of power grid infrastructure related regions

The income of current distribution network upgrading project projects is apportioned based on the proportion of the original fixed assets of the project to the original fixed assets of the regional power grid. The allocation model is as follows.

$$
I_{p}^{t}=I_{1}^{t} \times \xi^{t}
$$

where $I_{p}^{t}$ represents the income of the distribution network upgrading project, $\xi^{t}$ represents the income distribution ratio of the distribution network upgrading 
project, that represents, the proportion of the original value of the fixed assets of the distribution network upgrading project in the grid of the relevant region.

(3) Construction of life-cycle income model for distribution network upgrading projects

Based on the above analysis of the life-cycle income of power grid infrastructure, the income model is as follows:

$$
I_{p}=\sum_{t=1}^{T}\left(I_{1, d}^{t}+I_{1, g}^{t}\right) \times \xi^{t}
$$

where $I_{p}$ represents the total revenue of the distribution network upgrading project.

\subsection{Construction of the Life Cycle Input-Output Model of Power Grid Infrastructure}

(1) Net present value model

Integrate the income cash flow and expenditure cash flow of the entire life cycle of the power grid infrastructure to build a net present value model of the entire life cycle of the power grid infrastructure, as shown below:

$$
N P V=\sum_{t=1}^{T} \frac{1}{(1+r)^{t}} \times\left[I_{1}^{t} \times \xi^{t}-\left(C_{2}^{t}+C_{3}^{t}+C_{4}^{t}\right)\right]-C_{1}-C_{5} \times \frac{1}{(1+r)^{T}}
$$

where NPV represents the net present value of the entire life cycle of the distribution network upgrading project.

(2) Internal rate of return model

Net present value rate (NPVR) refers to the ratio of project net present value to original investment present value. Compared with the net present value, the net present value rate pays more attention to the economic benefits of unit investment.

$$
N P V R=\frac{\sum_{t=1}^{T} \frac{1}{(1+r)^{t}} \times\left[I_{1}^{t} \times \xi^{t}-\left(C_{2}^{t}+C_{3}^{t}+C_{4}^{t}+C_{5}\right)\right]-C_{1}}{C_{1}}
$$

where NPVR represents the life cycle net present value rate of distribution network upgrading projects.

(3) Input-output ratio model

According to the project's life cycle cash flow table, a dynamic input-output ratio model for distribution network upgrading projects is established, and the inputoutput ratio is the ratio of the present value of the project output cash flow to the present value of the project input cash flow.

$$
H=\frac{\sum_{t=1}^{T}\left[I_{1}^{t} \times \xi^{t} \times \frac{1}{(1+r)^{t}}\right]}{C_{1}+\sum_{t=1}^{T}\left[\left(C_{2}^{t}+C_{3}^{t}+C_{4}^{t}+C_{5}\right) \times \frac{1}{(1+r)^{t}}\right]}
$$

where $\mathrm{H}$ represents the life-cycle input-output ratio of the distribution network upgrading project.

\section{Empirical analysis}

A substation is located in $\mathrm{T}$ province. The existing scale of the substation cannot meet the development of regional load. Therefore, it is necessary to construct and start the A substation. In this period, two 240MVA main transformers will be constructed, and two $220 \mathrm{kV}$ overhead lines will be newly built. The length of the new power supply line will be 14.17 kilometers.

\subsection{Forecast of Increased Power Supply in Related Grids}

The economic benefit of distribution network upgrading projects is the income generated by increasing power supply. Increasing the power supply is a new power supply based on the original power supply capacity, that is, the power load minus the original power supply capacity.

(1) Load forecast of relevant regional power grids

Based on the development of the $\mathrm{N}$ region, the load growth rate is predicted to be $7 \%$ from 2020 to 2022 , the load growth rate to be 5\% from 2023 to 2032, the load growth rate to be $2 \%$ from 2033 to 2040 , and, the load growth rate to be $0 \%$ from 2041 to 2044 .

(2) Forecast of increased power supply

Combined with load forecasting and existing regional power supply capacity, the trend of increasing power supply capacity throughout the life cycle of $\mathrm{X}$ distribution network upgrading projects is shown in Fig.2.

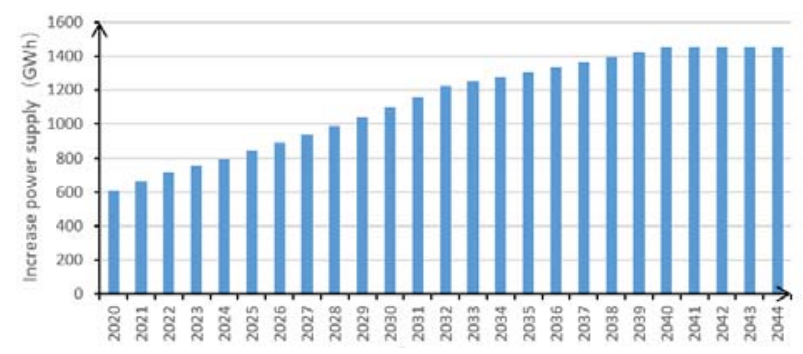

Fig. 2. Prediction of increased power supply capacity during the entire life cycle of $\mathrm{X}$ distribution network upgrading project

\subsection{Life Cycle Input Calculation of X Distribution Network Upgrading Project}

Calculate the various costs of the $\mathrm{X}$ distribution network upgrading project in each year of the entire life cycle.

(1) Construction cost. $\mathrm{X}$ distribution network upgrading project project construction investment was $23,587,700$ yuan.

(2) Operation and maintenance costs. The annual operation and maintenance cost of the $\mathrm{X}$ distribution network upgrading project is set to $2 \%$ of the initial investment, which is 4.61 million yuan per year.

(3) Cost of line loss. It is estimated that the line loss rate of the $\mathrm{X}$ distribution network upgrading project is $1 \%$, and the line loss cost is the product of the line loss power and the average power purchase price.

(4) Common cost allocation value. The annual utility cost allocation value of the $\mathrm{X}$ distribution network upgrading project is 1.2 million yuan.

(5) Decommissioning costs. The decommissioning costs account for $0.5 \%$ of the project's initial investment.

(6) Total investment in the whole life cycle of $X$ distribution network upgrading project. Based on the above-mentioned various costs, the total investment during the operation period of $\mathrm{X}$ distribution network 
upgrading project is obtained. The results are shown in Fig.3.

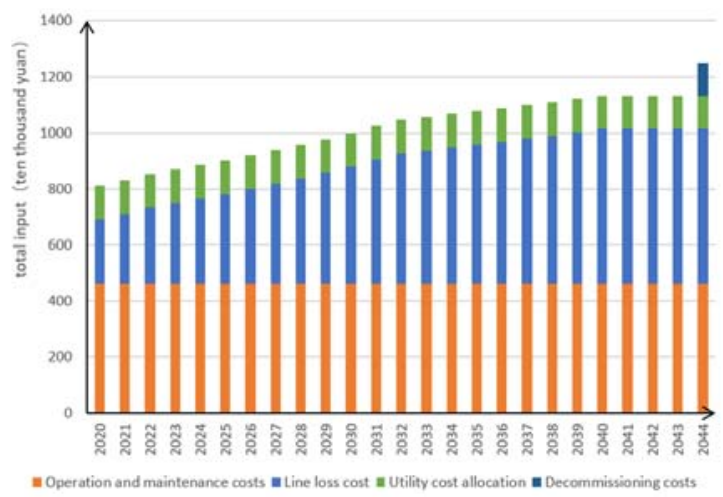

Fig. 3. Total input of each year in the operation period of $X$ distribution network upgrading project.

\subsection{Life Cycle Output Calculation of $X$ Distribution Network Upgrading Project}

The transmission and distribution income model is used to calculate the annual transmission and distribution income. The income from transmission and distribution is shown in Fig.4.

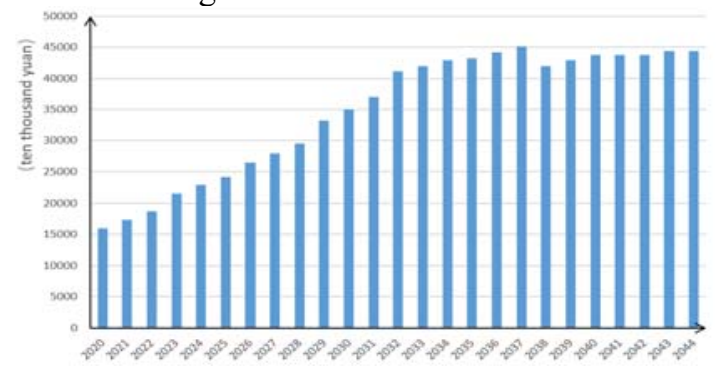

Fig.4 A transmission and distribution income for the whole life cycle of $\mathrm{X}$ distribution network upgrading project

\subsection{Calculation of Input-Output Indicators of $X$ distribution network upgrading project}

With a benchmark rate of return of $8 \%$, Table 4-4 shows the input-output indicators for the $\mathrm{X}$ distribution network upgrading project. Net present value NPV $=31.47$ million yuan, IRR $=9.26 \%$, net present value rate NPVR $=14 \%$, input-output ratio $\mathrm{H}=1.43$.(Table. 1 )

Table 1 Calculation results of input-output indicators of $\mathrm{X}$ distribution network upgrading project

\begin{tabular}{|c|c|}
\hline Input-output indicators & Index value \\
\hline Net present value & $31,470,000$ yuan \\
\hline Internal Rate of Return & $9.26 \%$ \\
\hline Net present value ratio & $14 \%$ \\
\hline Input-output ratio & 1.43 \\
\hline
\end{tabular}

\section{CONCLUSION}

This paper presents a method for evaluating the economic benefits of distribution network upgrading projects adapted to China's transmission and distribution tariff reform. The life cycle input and output of distribution network upgrading projects are summarized and analyzed, and a dynamic input-output model is established. The empirical analysis results show that the model can adapt to the dynamic changes of transmission and distribution tariff in the future, reflect the inputoutput situation of distribution network upgrading projects, and provide support for grid company investment decisions.

\section{Acknowledgment}

The paper is supported by "Research on precise investment decision of distribution network based on the development demand of Ubiquitous Electric Internet of Things"(State Grid Ningxia Electric Power Company technology projects).

\section{References}

1. Alaqeel, T.A., Suryanarayanan, S., 2019. A comprehensive cost-benefit analysis of the penetration of Smart Grid technologies in the Saudi Arabian electricity infrastructure, Utilities Policy, 60, 100933,

2. Han Meng, Dong Ning, Jiao Jianlin, Tian Jiaying, Wang Haoqiang. 2020. Research on Construction of Holographic Intelligent Operation Management and Control System for Beijing Power Grid Automation, Distribution \& Utilization 37(02), 47-53.

3. He, Y.H., Wang, B., Li, D.C., Du, M., Huang, K.R., Xia, T., 2015. China's electricity transmission and distribution tariff mechanism based on sustainable development, International Journal of Electrical Power \& Energy Systems, 64, 902-910.

4. LUO, G.L., YUAN, X.H., ZHANG, X.Y., 2011. Evaluating Power Grid Enterprise's Investment Returns, Energy Procedia, 5, 224-228.

5. Liu Dun Nan, Hou Rui, Li Qiang, Zhao Ning Ning, Ge Rui, Lu Yi. 2019. Research on fuzzy enhancement algorithms for infrared image recognition quality of power internet of things equipment based on membership function, Journal of Visual Communication and Image Representation, 62, 359-367.

6. Wang, Y.L., Zhang, F.L., Zhang, Y.Y., Wang, X.H., Fan, L.S., Song, F.H., Ma, Y.Z., Wang, S., 2019. Chinese power-grid financial capacity based on transmission and distribution tariff policy: A system dynamics approach, Utilities Policy, 60, 100941.

7. Chen Yan, Song Yinghua. 2020. Research on Architecture Design and Key Technologies of New Distribution IoT Back-end System, Distribution \& Utilization, 37(02), 41-46. 